\title{
Technological Catch-Up and Innovative Entrepreneurship in Vietnamese Firms
}

\author{
Claudio Petti ${ }^{1, *(\mathbb{D}}$, Minh Nguyen Dang Tuan ${ }^{2}$, Tuan Nham Phong ${ }^{3}{ }^{(0)}$, Mai Pham Thi $^{2}$, Thao Ta Huong ${ }^{2}$ \\ and Vishnu Varthan Perumal ${ }^{4}$
}

check for updates

Citation: Petti, Claudio, Minh Nguyen Dang Tuan, Tuan Nham Phong, Mai Pham Thi, Thao Ta Huong, and Vishnu Varthan Perumal. 2021. Technological Catch-Up and Innovative Entrepreneurship in Vietnamese Firms. Administrative Sciences 11: 100. https://doi.org/ 10.3390/admsci11030100

Received: 31 July 2021

Accepted: 6 September 2021

Published: 10 September 2021

Publisher's Note: MDPI stays neutral with regard to jurisdictional claims in published maps and institutional affiliations.

Copyright: (c) 2021 by the authors. Licensee MDPI, Basel, Switzerland. This article is an open access article distributed under the terms and conditions of the Creative Commons Attribution (CC BY) license (https:// creativecommons.org/licenses/by/ $4.0 /)$.
1 Department of Engineering for Innovation, University of Salento, 73100 Lecce, Italy

2 KisStartup, Hanoi 100000, Vietnam; nguyendangtuanminh@gmail.com (M.N.D.T.); mai.kisstartup@gmail.com (M.P.T.); thao.kisstartup@gmail.com (T.T.H.)

3 School of Business Administration, University of Economics and Business, Vietnam National University, Hanoi 100000, Vietnam; tuannp@vnu.edu.vn

4 Department of Business and Management, LUISS University, 00198 Rome, Italy; vishnuvarthan212@gmail.com

* Correspondence: claudio.petti@unisalento.it

\begin{abstract}
The article analyses the dynamics of technological catch-up through entrepreneurship in latecomer firms to emerging markets. With this aim, the article introduces Vietnam's experience and illustrates the result of three case studies of Vietnamese technology firms at different stages of their evolution. Insights from the cases reveal all follow an incremental innovation model based on business model 'soft' innovations, mainly in customer-facing activities and partnering, as well as limited products and technology adaptation to local market needs. Consistently with latecomer firms theory, the market drives these firm's innovation efforts, which are concentrated on developing new services and comprehensive solutions rather than new technologies. Comparisons of the findings with recent and similar experiences of Chinese firms highlight that different stages of catch-up lead to different innovation practices in nature and degree, and the need to strengthen institutions to face competition, rather than use the former to shelter from the latter. The Vietnamese firms' innovation practices and catch-up patterns found are then discussed under the perspective of reaping the benefits of international knowledge and technology flows and the specific challenges faced by Vietnam. The paper concludes with several reflections, lessons learned and perspectives for other newly industrializing emerging countries.
\end{abstract}

Keywords: catch-up; latecomer firms; entrepreneurship; tech-based firms; Vietnam

\section{Introduction}

\subsection{Late-Industrializers, Technological Catch-Up and Latecomer Firms}

Industrialization happens by imitation of the forerunner (Gershenkron 1962). According to the author, this mainly happens by importing technologies and knowledge from abroad. Nonetheless, industrialization has never been a pure imitative process since it has always happened in combination with different, indigenously determined elements. Abramovitz's (1986) social capability concept and learning through imitation and apprenticeship via technologies transferred from abroad (Amsden 1989; Westphal 2002) are the main of such indigenously determining elements that make a country able to absorb and exploit advanced technologies. East-Asian, late industrializing economies, in particular, made strong and distinctive use of learning as the prominent technological catch-up mode and entrusted the firms as the key actors in this process (Amsden 1989).

Most of these firms share the common characteristic of being latecomers (Hobday 1995; Mathews 2002), i.e., 'forced' late entrants to an industry, suffering the competitive disadvantage of initially lacking technology and market access. Paraphrasing Amsden (1989), because of their technological disadvantage, latecomer firms are also 'forced learners' that 
must be based on a combined set of some initial advantages, such as low wages, government support and borrowed technology, to bring incremental productivity and quality improvements to existing products and enhance their price and quality competitiveness to eventually catch-up. On the other hand, because latecomers' distance from the frontier of technology generates a productivity gap that makes stronger and faster the potential for a rapid advance (Abramovitz 1986), latecomers' technology backlog and backwardness carry an inherent initial advantage (Gershenkron 1962) for technological catch-up. Nonetheless, such an advantage dissipates over time as the frontier approaches. We refer to these firms as emerging markets latecomer firms (EMLCFs).

Because of the internal and external resources' limitations, these firms have to look first for critical resources externally while trying to catch up with internal development (Amsden 1989). Targeting under-served market niches overlooked by incumbents (Li and Kozhikode 2008; Wu et al. 2010) to avoid direct competition is the rule in the initial catch-up phases. For this purpose, borrowing technology from abroad is a better means, since allowing latecomer firms to enhance price and quality competitiveness through incremental improvements (Amsden 1989) allows them to learn how to produce at world levels of efficiency, advancing their competitiveness beyond their technological development capabilities (Westphal 2002).

Entrepreneurial firms make no exception, and innovative entrepreneurship, because of its effects on innovation, economic growth, welfare and job creation (Block et al. 2017), may accelerate the technological catch-up process. Entrepreneurship fuels innovation by transforming potential technological opportunities into new and marketable products. In doing so, it not only reinforces local firms' innovative capacity but also, through this latter, fosters economic growth through productivity increases. Block et al. (2017) report evidence collected about the positive correlation between entrepreneurial activity and innovation capacity and of this latter with economic growth. In addition, more entrepreneurship, and especially high-growth, innovative entrepreneurship, then leads to the generation of more resources for local development through taxes' income as well as high-quality jobs and, ultimately, through new products development and commercialization, increased quality of life; think about pharmaceuticals for instance. Moreover, the inherent nature of innovative entrepreneurship, inherently based on knowledge-intensive, technologybased and research-driven opportunities (Acs et al. 2009), favors the creation of that kind of transformative absorptive capacity (see Petti et al. 2019a), which facilitates the assimilation and exploitation of knowledge spill-overs. Finally, innovative start-ups fuel local innovation not only directly, but also indirectly by creating a dynamic environment conducive to the return, retention and attraction of talents able to fuel those higher-level technological capabilities needed for sustained and sustainable technological catch-up.

\subsection{Innovation, Entrepreneurship and the Role of the State}

There is, therefore, a virtuous and circular relationship between entrepreneurship and innovation as they influence each other, generating the potential of a spiraling of growth. Nonetheless, Block et al. (2017), mirroring Baumol's (1990) seminal work about productive and unproductive entrepreneurship, reports as only a small number of innovative, highgrowth ventures, which represent from two to six percent of the enterprise population for most countries, actually produce the sought benefits above. Therefore, not every innovative entrepreneurship endeavor has the potential to spur technological catch-up and reap its benefits. In fact, most latecomer firms rest trapped in aborted catch-up cycles (Malerba 2002) and even more never produce any benefit for local economic and social development. Most entrepreneurs, in fact, do not employ personnel, are home-based and earn low incomes (Shane 2009). This is true for traditional, as well as 'wannabe' innovative entrepreneurs. As a matter of fact, the resource constraints of EMLCFs and the environment in which they operate may make large chunks of innovative entrepreneurship ineffective. This is because of being too incremental, too soft, too marginal to produce any of the effects sought.

That is why the role of the state is very relevant in such contexts. Many governments have, in if fact, paid increasing attention to entrepreneurship and have implemented 
a number of policies aimed at fostering it in both developed and developing countries (Minniti 2008). However, although necessary, it is not a sufficient condition, since, especially innovative entrepreneurship, requires not only to push and promotion but also to devise the necessary incentives and allocative mechanisms that favor productive against unproductive or ineffective entrepreneurship. This is easier to write than do, since in Shane's (2009) parlance, there is good and bad entrepreneurship policies. As a matter of fact, most of the debate about the role of the state and government policies in this field can be summarized by the issue of effectiveness against non-effectiveness of government intervention and policies (e.g., Fritsch and Mueller 2007; Cumming and Fischer 2012; Shane 2009; Acs et al. 2016; Fairlie et al. 2011, 2016).

If one wants to stimulate the desired kind of innovative entrepreneurship, the whole question can be synthesized in assuring the set up of appropriate institutions, policies and incentives that can generate the appropriate allocation of entrepreneurial resources. That is steering entrepreneurs and entrepreneurial behaviors towards 'productive' entrepreneurship behaviors. Over time entrepreneurship policies have tried a number of tools from education, financing and taxations to international trade regulations, through encouragement to pursue innovative activities and removal of obstacles to them, such as reducing red tape and regulating intellectual property rights (IPR). The overall intent of such policies, in emerging economies especially, was to create an appropriate and institutional environment, both in terms of formal and informal institutions (North 1990) conducive to productive entrepreneurship (Minniti 2008) and the development of autonomous national innovation and entrepreneurial ecosystems.

However, most of the research about these attempts, at both firm and aggregate level, with specific reference to innovative entrepreneurship, has been carried out in industrialized and highly developed countries. Except for some notable studies carried out in late-industrializers, such as the ones of Dutz et al. (2000); Acs and Szerb (2007), up until the related literature review of Block et al. (2017), very few studies use a non-European or non-US sample. Furthermore, the possible methodological or coverage limitations of such a review, it is undeniable that emerging economies and their firms are under-represented in the literature about innovative entrepreneurship.

\subsection{Study Objective}

Starting from the limitations highlighted above, the purpose of this paper is to analyze the dynamics of technological catch-up through entrepreneurship in emerging markets latecomer firms. More specifically, it does so by investigating and providing preliminary evidence of how innovative entrepreneurship works in Vietnamese enterprises. In addition, it discusses how the path followed compares with previous ones, with particular reference to the Chinese experience. In this aim, the cases of three technology-based companies based in Hanoi are analyzed.

By focusing on Vietnamese firms, this paper first adds to the innovative entrepreneurshiprelated literature with evidence collected from a non-EU or US sample. Second, it makes a further step by portraying the entrepreneurial ecosystem of a critical sector, i.e., ICTs and the key characteristics of the technological start-ups of one of the latest industrializers and fastest-growing emerging countries. A country, in addition, with an institutional setting and a catch-up experience that differs not only from the US and EU and textbook-based experiences but also from the previous developmental path of regional pioneers (i.e., South Korea, Singapore, Hong Kong S.A.R. and Taiwan) and even from China, its most close counterpart, in time, space and institutional setting as well. For this reason, findings will be discussed against previous studies undertaken in a Chinese context.

\section{Study Context}

Since Vietnam has been implementing its Đổi mới policy in 1987, the country invests in a global economy by favoring permeable borders to foreign investments and commercial activities (Di Tommaso and Angelino 2019). Entrepreneurship was formally accepted in 
Vietnam in the 1990s. Then the concept was more related to individual initiative and non-state firms. Now, it is more understood as attached to technology and innovation. To support and promote innovative start-ups, the Vietnamese government issued a number of financial policies, including direct supporting policies, such as tax and credit policies, and indirect supporting policies through the incubator model. Currently guided by an aggressive agenda to spur learning and innovation-Vietnam 2035-the government created a number of funds at the state and provincial/city level to support start-ups. In addition, collaboration with countries and banks in order to gather further funding and develop innovation programs to provide loans, technical training, and business mentoring have been established. Table 1 below reports examples of such programs (Table 1).

Table 1. Examples of governments' start-up support.

\begin{tabular}{|c|c|}
\hline Programs Type & Examples \\
\hline Country-level programs & $\begin{array}{l}\text { National Technology Innovation Fund (NATIF) is a government } \\
\text { agency and financial institution under Vietnam's Ministry of } \\
\text { Science and Technology that provides grants and preferential } \\
\text { loans for R\&D, innovation and technology transfer. } \\
\text { The National Agency for Technology, Entrepreneurship, and } \\
\text { Commercialization Development (NACD) is a national platform } \\
\text { under Vietnam's Ministry of Science and Technology that } \\
\text { provides training, mentorship and financial aid to start-ups. }\end{array}$ \\
\hline $\begin{array}{l}\text { Provincial/city-level } \\
\text { programs }\end{array}$ & $\begin{array}{l}\text { The SpeedUP is a VND } 11.75 \text { billion (USD 520,520) fund, which } \\
\text { has been started by Ho Chi Minh City's Department of Science } \\
\text { and Technology. The fund invests in } 14 \text { start-ups, with } \\
\text { investments ranging from VND } 350 \text { million (USD 15,500) to VND } \\
1282 \text { billion (USD 56,792). } \\
\text { Startup city.vn is an online platform launched by Hanoi's People } \\
\text { Committee that has details about start-ups and investors and } \\
\text { aims to connect investors with entrepreneurs. } \\
\text { Saigon Silicon City Center is a 52-hectare complex, which is being } \\
\text { built to support tech-focused start-ups and international firms. It } \\
\text { is expected to attract investments worth USD } 1.5 \text { billion by } 2020 \text {. } \\
\text { Mobile Applications Laboratory (mLab) East Asia was launched } \\
\text { by Ho Chi Minh City and has an incubation program that focuses } \\
\text { on mentoring, training, access to equipment and financing. }\end{array}$ \\
\hline $\begin{array}{l}\text { Collaborations with } \\
\text { countries and banks }\end{array}$ & $\begin{array}{l}\text { Vietnam-Finland Innovation Partnership Programme is a } \\
\text { program financed jointly by both governments. It is currently in } \\
\text { its second phase through } 2014-2018 \text { and has a budget of EUR } 11 \\
\text { million. The fund's investments focus on innovative companies } \\
\text { that are aiming for international growth and currently includes } 18 \\
\text { innovative companies and } 5 \text { high-growth start-ups in their } \\
\text { portfolio. } \\
\text { Mekong Business Initiative is a partnership program between the } \\
\text { Asian Development Bank and the Government of Australia that } \\
\text { focuses on alternative financing, including venture capital, angel } \\
\text { investments, and fin-tech in Cambodia, Laos, Myanmar and } \\
\text { Vietnam. }\end{array}$ \\
\hline
\end{tabular}

In terms of the workforce, the high-quality investments made in the education system in recent years created momentum, especially for Vietnam's information and communication technology (ICT) industry to develop. The wave of technology investment and digital transformation is opening up a breakthrough opportunity for Vietnam's ICT industry to transform itself from outsourcing to innovation. Driven by its growing internet penetration, smartphone adoption and young demographics, Vietnam offers a wealth of opportunities for entrepreneurial start-ups and tech-based firms, not only in the ICT industry, such as fin-tech, e-commerce but also in food technology, all three having been top priorities for investors in the past few years. 
Vietnam currently has around 3000 start-ups involved in sectors such as fin-tech, ecommerce, food tech and healthcare. In 2017, 92 start-ups received investments worth USD 291 million, 42 percent higher compared to 2016, while the number of start-ups increased by 45 percent. Most of these firms just passed the first stage of establishment, and now they are going into the second phase of development. In 2000, technology companies sprouted up in Vietnam, but it was in 2016 that the country's innovative entrepreneurship ecosystem eventually takes a defined shape. In only 2 years, Vietnam jumped from the second least active start-up entrepreneurial ecosystem among the six largest ASEAN countries into the third most active, behind only Indonesia and Singapore (Tech Sauce 2021) In the following, the Vietnamese entrepreneurial ecosystem is described in detail. The relevance of co-working space is one of its peculiar characteristics.

As already illustrated, the government plays a prominent role, mainly by encouraging entrepreneurship, setting up a number of direct and indirect supporting policies and establishment of a number of funds favoring collaborative initiatives.

Then there are education institutes, which play a fundamental role in fostering young people's entrepreneurial spirit. Earlier, Vietnam followed the Chinese education system that focused on memorizing rather than individual critical thinking. At the end of the 20th-century, education changed and more awareness about the relevance of innovation for the economy and growth spread in education institutes, which integrated innovation and entrepreneurship content in their curricula. Moreover, positive attitudes towards enterprises and self-employment targeting youth were encouraged by creating awareness during secondary and technical education.

Furthermore, there are a number of privately run, public, university-based and privatepublic-partnership incubators and accelerators. Incubators in Vietnam are blooming with the participation of not only local government agencies and universities, and private sectors but also programs jointly organized by international incubators. They became a bridging platform for start-ups that fills the gaps in businesses development stages. There are hundreds of notable incubators and accelerators in Vietnam in all major cities, such as Hanoi, Ho Chi Minh City, Da Nang, Dong Thap and Hue. Particularly Hanoi is home to accelerator programs from Hatch Ventures, Angel, KisStartup, X-Incubator, IDG Ventures Vietnam, Saigon Hi-Tech Park (SHTP Incubation Center) and 5Desire.

Concerning funders, along with the traditional start-up funding sources represented by angel investors and venture capital nurturing start-ups all over the country, there is a growing recourse to crowdfunding platforms and micro-investors.

As mentioned, co-working spaces are one of the key drivers behind the growth of the Vietnamese entrepreneurial ecosystem. The number of co-working spaces in Vietnam rises every year, driven by the growth in start-ups and the need for cost-effective spaces compared to existing leased office spaces. The growing demand has not only attracted domestic start-up firms but also global firms and investment funds. It is expected that such spaces will continue to expand for start-ups as well as for small, established enterprises looking to minimize costs and increase flexibility.

Finally, there are innovative Vietnamese enterprises. Before, they were only software outsourcers for export. In recent years, Vietnam's enterprises started to develop their own software products and become providers of their own solutions to foreign customers.

How do these new enterprises work? Could the previous models and experiences help? The following sections investigate the responses to these questions.

\section{Materials and Method}

In order to investigate how innovative entrepreneurship works in Vietnamese enterprises, with the final aim to unveil preliminary insights about the dynamics of technological catch-up through entrepreneurship in emerging markets' latecomer firms, the research design followed a multiple case study approach. The case study method has been chosen since it is particularly appropriate for the novelty of the topic in the specific context and the question at hand. Since a case study is an activity based on discovery rather than on 
confirmation, it allows deepening of the knowledge of a process, rather than its individual products, and the understanding of a context, rather than specific variables. It focuses on an event in the space and time in which it occur and records the most significant characteristics of real-life events, which is what was wanted to be ascertained in this specific study.

More specifically, three case studies were selected among Vietnamese technology firms at different stages of development using theoretical sampling (Eisenhardt 1989) with the aim to have an overview of different typologies of exemplar firms and detecting regularities among the different stages of technology firms' life. Insights from previous similar studies in technology entrepreneurship and latecomer firms (e.g., Petti and Zhang 2014; Petti et al. 2019a) highlighted some factors, such as business model innovations might be confused with mere inherent business model adjustments at the start-up stages. On the other hand, there are other peculiar characteristics of latecomer firms, such as the low degree of innovation that remains well beyond the initial start-up stage, to the point of having been advocated as a kind of a latecomer model on its own. Although in this work, this latter is rather believed to be the highway to aborted catch-up. These are the main reasons to choose companies at different stages of development, whereas the choice of specific companies, which the specific profile is reported in the first column of Table 2, was based on the suggestion of the Vietnamese partner of the study, an innovation consultancy and incubator accompanying Vietnamese start-ups since 2015.

The triangulation of data collection was followed at a single case-study level by using desk-based analyses of target enterprises' websites and documents coupled with interviews and follow-up contacts for information checks and validation of cases' reports.

The first step was to prepare a case protocol based on the adaptation of one used in previous studies in a similar context. This protocol started with the sharing of a case study background information sheet, which described clear information about the project background, including the objectives, specific information to be collected and effort required to conduct the interview process, along with privacy terms and conditions. In this way, the companies and informants involved could make an informed decision on whether, and with what level of engagement, to participate to the study. In addition, these guidelines established clear, understandable methods of executing tasks, which allows seamless collaborating on the collection of information. Then an interview guide was prepared with questions aimed to collect information on how the company manages knowledge and technologies to innovate, and in particular about knowledge processes, business model innovation practices and their impacts on technology and innovation capabilities, as well as on overall performance. More specifically (see Appendix A):

- Company key products, related knowledge;

- How the company developed these products;

- How knowledge is usually gained, created, managed to develop new products;

- Company's business model innovation practices;

- Company's innovation performance and overall performance.

Finally, following the interview guide structure, a specific analysis (excel) and a case study report template were developed to help structure the information collected (the former) and organize it in a consistent narrative (the latter) to undertake subsequent assembling, summarization and comparative analyses.

Once the protocol was established, and the criteria for theoretical samples identified, one start-up (less than 3 years old), one new technology-based firm (more than 3-years old and less than 8 years old) and one established firm (more than 8 years old) were sought via the collaboration of host institution colleagues and contacts.

Three of such technologically innovative start-ups and firms agreed to participate. These firms were privately owned software firms active in the ICT industry, and more specifically in: (1) Apartment management system (property management technology); (2) HRM SaaS (human resource management software-as-a-service); (3) SMS system (smart manufacturing solutions system). 
Data collection was undertaken between November and December 2019. Each case started with an analysis of secondary sources (i.e., companies' websites, documents and social network channels). These were to prepare the for interview to make it more focused on the specific research objective.

The interviews (open-ended and face-to-face), with a duration of about $1.5 \mathrm{~h}$, started with the request to introduce how the company manages knowledge and innovation and then focused on knowledge processes, business model innovation practices and their impacts on technology and innovation capabilities. The interview guide, made more as a checklist of information required rather than a sequence of questions and based on a limited set of open-ended questions, was prepared to engage the interviewee in telling a story and record key insights without interrupting, allowing to following of the interviewee's narrative. Then remaining required information was easily spotted in the interview guide and integrated with direct questions at the end.

Then after the interview, the information gained was noted following the interview guide in a case study interview record that circulated within the interview team for review, clarifications and integrations. Once a stable and agreed version was developed, requests for clarifications were resubmitted via e-mail and telephone to the interviewee.

After this, the case study records were re-arranged into case reports following a standard format reporting (in order): company background, innovation process, knowledge (divided into knowledge sources, knowledge processes and knowledge outcomes), technology innovation, business model innovation, performance and internal notes (interview data and possible questions for future interviews, if any). The case closed when the interviewee provided her/his validation to the report. Overall, the whole interview, follow-up contacts and validation process took informants about three hours. Information and data about informants and companies, as established and agreed by the exchange and clarifications of the case study background at the first contact and interview occurrence, were kept anonymous.

Thereafter, for each case and then across cases, the information collected was analyzed through data reduction and summarizing of patterns and gradually condensed into concepts by focusing on the main information sought (Eisenhardt 1989; Yin 1994).

\section{Results}

The information collected in each case analyzed is summarized in Table 2 below. For confidentiality reasons, company names are omitted, and the information aggregated, trying to maintain the best possible accuracy and precision of the data. The information that for these reasons is not reported was, however, useful for contextualizing the cases and for understanding the orientation of some data in the specific sector. 
Table 2. Case summaries.

\begin{tabular}{|c|c|c|c|c|c|c|c|c|c|}
\hline & $\begin{array}{c}\text { General } \\
\text { Information }\end{array}$ & Innovation Process & Knowledge Types & $\begin{array}{l}\text { Knowledge Sources } \\
\text { and Channels }\end{array}$ & $\begin{array}{c}\text { Knowledge } \\
\text { Processes }\end{array}$ & $\begin{array}{c}\text { Knowledge } \\
\text { Outcomes }\end{array}$ & $\begin{array}{l}\text { Technology } \\
\text { Innovation }\end{array}$ & $\begin{array}{l}\text { Business Model } \\
\text { Innovation }\end{array}$ & $\begin{array}{c}\text { Overall } \\
\text { Performance }\end{array}$ \\
\hline $\begin{array}{c}\text { CASE } 1 \\
\text { Apartment } \\
\text { management system } \\
\text { (Start-up) }\end{array}$ & $\begin{array}{c}\text { Three-year-old } \\
\text { private-owned } \\
\text { company; } \\
\text { small-sized, around } \\
15 \text { employees, } \\
\text { company made } \\
\text { revenue of around } \\
\text { USD 100,000 in } 2018 \\
\text { About } 25 \% \text { of } \\
\text { Vietnamese market } \\
\text { share and } 3 \% \\
\text { international market } \\
\text { share. }\end{array}$ & $\begin{array}{l}\text { Utilized existing } \\
\text { technology in order } \\
\text { to fill the market gap } \\
\text { and developed } \\
\text { property } \\
\text { management. }\end{array}$ & $\begin{array}{l}\text { More codified than } \\
\text { tacit. External } \\
\text { knowledge: codified. } \\
\text { Internal knowledge: } \\
\text { tacit. }\end{array}$ & $\begin{array}{l}\text { Work Experience, } \\
\text { market } \\
\text { opportunities and } \\
\text { available technology. } \\
\text { Conference and } \\
\text { meetings. }\end{array}$ & $\begin{array}{l}\text { Acquired knowledge } \\
\text { from different clients } \\
\text { internationally and } \\
\text { domestically, rely on } \\
\text { adaptation of } \\
\text { existing } \\
\text { technologies. }\end{array}$ & $\begin{array}{l}\text { Continuously } \\
\text { enriching and } \\
\text { processing } \\
\text { knowledge from the } \\
\text { market, the } \\
\text { company reports } \\
\text { their knowledge } \\
\text { processes' } \\
\text { performance is } \\
\text { ahead of their main } \\
\text { competitors. }\end{array}$ & $\begin{array}{l}\text { Firm mainly focused } \\
\text { on modification to } \\
\text { their existing } \\
\text { product, } \\
\text { continuously } \\
\text { building, measuring } \\
\text { and learning from } \\
\text { the market signals to } \\
\text { upgrade the key } \\
\text { features of their } \\
\text { products. }\end{array}$ & $\begin{array}{l}\text { Quite limited. } \\
\text { Revenue model } \\
\text { stable since } \\
\text { inception. Changes } \\
\text { in key partners, key } \\
\text { resources and } \\
\text { customer } \\
\text { relationships } \\
\text { elements }\end{array}$ & $\begin{array}{l}\text { The company ranks } \\
\text { as ahead in terms of } \\
\text { market share and } \\
\text { operational } \\
\text { effectiveness. }\end{array}$ \\
\hline $\begin{array}{c}\text { CASE 2 } \\
\text { HRM SaaS } \\
\text { (New } \\
\text { Technology-based } \\
\text { Firm) }\end{array}$ & $\begin{array}{c}\text { Privately owned, } \\
\text { 4-year-old company } \\
\text { established in } 2015 . \\
\text { In } 2018 \text { the overall } \\
\text { revenue was more } \\
\text { than USD 20,000 } \\
\text { approximately. } \\
\text { Acquired } 1 \% \text { of } \\
\text { Vietnamese market } \\
\text { share. }\end{array}$ & $\begin{array}{l}\text { Focused on SaaS } \\
\text { HRM software in a } \\
\text { cost effective and } \\
\text { flexible way more } \\
\text { than existing } \\
\text { products. }\end{array}$ & $\begin{array}{c}\text { TAPS-FCS } \\
\text { knowledge, RAD } \\
\text { skills, IoT } \\
\text { knowledge for } \\
\text { product } \\
\text { development. }\end{array}$ & $\begin{array}{l}\text { Universities, start-up } \\
\text { training institutes, } \\
\text { incubators, meetings, } \\
\text { software consultant } \\
\text { and business links. }\end{array}$ & $\begin{array}{l}\text { Informal knowledge } \\
\text { acquisition, } \\
\text { cross-departmental } \\
\text { meetings, personnel } \\
\text { mobility and } \\
\text { training. Recording } \\
\text { and storing } \\
\text { knowledge for } \\
\text { future use and } \\
\text { reverse engineering } \\
\text { adaptation of } \\
\text { existing technologies } \\
\text { for prototypes dev. }\end{array}$ & $\begin{array}{c}\text { Knowledge } \\
\text { processes perceived } \\
\text { as performing but } \\
\text { not in all ahead of } \\
\text { competitors. }\end{array}$ & $\begin{array}{l}\text { Firm's products are } \\
\text { modified from } \\
\text { existing products } \\
\text { and introduced for } \\
\text { the first time in local } \\
\text { market. }\end{array}$ & $\begin{array}{l}\text { Quite limited. } \\
\text { Revenue model } \\
\text { stable since } \\
\text { inception. Changes } \\
\text { in key partners, } \\
\text { channels, customer } \\
\text { relationships and } \\
\text { cost structure } \\
\text { elements. }\end{array}$ & $\begin{array}{l}\text { The company overal } \\
\text { market and financial } \\
\text { performance is rated } \\
\text { to be lagging in } \\
\text { comparison with } \\
\text { competitors in the } \\
\text { aspects of market } \\
\text { share, revenue and } \\
\text { profit. }\end{array}$ \\
\hline $\begin{array}{c}\text { CASE } 3 \\
\text { SMS system } \\
\text { (Established Firm) }\end{array}$ & $\begin{array}{l}\text { Nine-year-old } \\
\text { private-owned } \\
\text { joint-stock company; } \\
\text { performing business } \\
\text { process outsourcing. } \\
300 \text { employees and a } \\
\text { revenue of USD 10 } \\
\text { million. The } \\
\text { company's export } \\
\text { ratio is about } 75 \% \text {. }\end{array}$ & $\begin{array}{l}\text { The company } \\
\text { developed Vietnam's } \\
\text { first SMS and its } \\
\text { services that can } \\
\text { respond to current } \\
\text { global trends, such } \\
\text { as the innovative } \\
\text { technology of I4.0. }\end{array}$ & $\begin{array}{l}\text { Acquired APS_FCS } \\
\text { knowledge, RAD } \\
\text { skills and IoT } \\
\text { knowledge for } \\
\text { product } \\
\text { development. }\end{array}$ & $\begin{array}{c}\text { Japanese partners } \\
\text { work experience, } \\
\text { business links and } \\
\text { training. }\end{array}$ & $\begin{array}{c}\text { Importantly } \\
\text { practical training } \\
\text { through Japanese } \\
\text { partners' work and } \\
\text { inquiries. Learning } \\
\text { from external } \\
\text { knowledge, and the } \\
\text { company } \\
\text { implemented proof } \\
\text { of concept with } \\
\text { customers on small } \\
\text { scale. }\end{array}$ & $\begin{array}{l}\text { Knowledge } \\
\text { processes perceived } \\
\text { as performing at a } \\
\text { large scale and } \\
\text { acquired large } \\
\text { corporations. }\end{array}$ & $\begin{array}{l}\text { Firm's technological } \\
\text { innovation is only } \\
\text { one part of business } \\
\text { process innovation, } \\
\text { artificial intelligence, } \\
\text { building platforms; } \\
\text { data plays an equally } \\
\text { important role as the } \\
\text { technology itself. }\end{array}$ & $\begin{array}{l}\text { Changed its original } \\
\text { business model from } \\
\text { BPO company to } \\
\text { Smart Data Solutions } \\
\text { provider. Relevant } \\
\text { and comprehensive } \\
\text { change of all } \\
\text { business model } \\
\text { elements but } \\
\text { incremental rather } \\
\text { than radical changes. }\end{array}$ & $\begin{array}{l}\text { The company overal } \\
\text { market and financial } \\
\text { performance is } \\
\text { ahead of the } \\
\text { competitor. }\end{array}$ \\
\hline
\end{tabular}


Table 3 below shows the results of the cross-case analyses carried out through data reduction and model synthesis. This step of the analysis was necessary to aggregate all the data collected in a single place that shows the total result of the analysis to assemble and interpret the state of the art about the innovation practices and business model innovation.

Table 3. Case synthesis.

\begin{tabular}{ll}
\hline \multicolumn{1}{c}{ Factors } & Cases Synthesis \\
\hline Mnnovation process & Mainly adaptive and modular business model innovation. \\
& Technologies used were typically known and not new to the \\
& industry. Incremental product innovation based mainly on \\
& modifications and adaptations of existing products and \\
& technologies to develop new (to the firm) products. \\
& Novelty-related and triggered by the need to use the product \\
& in a different context. Therefore, a market-oriented innovation \\
& strategy was predominantly followed. \\
& $\begin{array}{l}\text { Product that is built on both, explicit and tacit knowledge } \\
\text { bases, considering techniques such as close collaboration, } \\
\text { Knowledge Types }\end{array}$ \\
& market observation, task analysis, probe interviewing and \\
& role-playing.
\end{tabular}

Customers, personal networks, events, inter-industry and

Knowledge Source and channels suppliers, competitors, market research, scientific knowledge, employee grafting, advisors, internet, investors, databases, grafting similar entrepreneurs, universities and incubators.

Knowledge acquired by both formal and informal exchanges and assimilated through cross-departmental meetings, personnel mobility and training. Knowledge transformation

Knowledge Process undertaken by recording and storing for future use and reverse engineering. Knowledge exploitation adaptation of existing technologies for the development of new prototypes for SMEs.

Knowledge processes perceived as performing but not all ahead of competitors. However, all show limited invention (and mainly domestic). Effectiveness and efficiency still to be witnessed.

Knowledge Outcomes

Modifications and/or adaptations of existing products and introduction for the first time in the local market. Limited

Technology Innovation new-to-the-firm technical innovation, but successful, sometimes commercialization with the 'new' products by capturing the market opportunities.

Quite limited to the adaptation of some elements of the business model. Only in one case extended to all elements,

Business Model Innovation relevant but not radical, following a path-dependent competence enhancing model. Key partners is the business model element changed in all the cases.

Overall Performance Market and financial performance perceived usually ahead of competitors.

Table 4 summarizes and depicts the business model innovations detected in the three cases analyzed. The colored cells indicate the components revised; their soft color indicates the incremental modification of the components. 
Table 4. Focus on business model innovation.

\begin{tabular}{lccc}
\hline & $\begin{array}{c}\text { CASE 1 Apartment } \\
\text { Management System }\end{array}$ & $\begin{array}{c}\text { CASE 2 HRM } \\
\text { SaaS }\end{array}$ & $\begin{array}{c}\text { CASE 3 Smart } \\
\text { Manufacturing Solution } \\
\text { System }\end{array}$ \\
\hline Key Partners & Revised & Revised & Revised \\
\hline Key activities & Unrevised & Unrevised & Revised \\
\hline Key resources & Revised & Unrevised & Revised \\
\hline Valur Proposition & Unrevised & Unrevised & Revised \\
\hline Customer segments & Unrevised & Unrevised & Revised \\
\hline Channels & Unrevised & Revised & Revised \\
\hline $\begin{array}{l}\text { Customer } \\
\text { relationships }\end{array}$ & Revised & Revised & Revised \\
\hline Cost Structure & Unrevised & Revised & Revised \\
\hline Revenue Structure & Unrevised & Unrevised & Revised \\
\hline Not
\end{tabular}

Note: soft color indicate the incremental nature of components' modification.

\section{Analyses and Discussion}

\subsection{Analyses}

From the findings, the following emerge according to each of the issues surveyed, starting from the use of external knowledge, which, especially for start-ups, is increasing in relevance. Due to their small size and newness, they cannot pay for strong protection mechanisms on their own and face challenges from knowledge spillovers. According to interviewees, there are several sources from which this necessary knowledge is acquired, and these sources are of different types. The following sources have emerged repeatedly: customers, personal network, events, market, regulation, inter-industry, university, vicarious learning, suppliers, competitors, market research, scientific knowledge, employee hunting, advisors, internet, investors, databases and work experience. The interviewees highlighted the importance of using different sources in order to combine them with their knowledge and make better decisions. Interviewees especially emphasized that using multiple contexts of sources is required for solving different problems. The entrepreneur's prior knowledge, formed through experience and education, emerged as an important factor. This leads to the relevance of absorptive capacity. However, the interviews highlighted it was not just a matter of prior knowledge and education. The entrepreneurs, in fact, emphasized personality traits of critical reflection and their cognitive mindset, especially about openness to external knowledge. Therefore, acquirable and unique characteristics interact in how knowledge is acquired, assimilated and made effective.

Personal networks emerged as an important source. Especially at the beginning of the business, the existing personal networks have been of high importance. Furthermore, in the same vein as neighboring Chinese entrepreneurs, finding the right external sources is stated as a central aspect in this discussion. However, due to the different stages of both countries' economic development and of the firms' lifecycle, in Vietnam, personal networks are more used for business development rather than 'to make things done', whereas this latter use has already been made for a while in China (see Petti and Zhang 2014). Maintaining contact with sources typically costs time and money for the start-up; finding the right external sources is, therefore, more important, especially at the early stages of technology-based firms' formation. Therefore, the benefit of the individual source needs to evaluate its relevance, quality and value. This, together with the kind of knowledge used, both tacit and explicit and the knowledge process, is not so different from other companies in other countries at comparable stages of development. Although the acquisition of explicit knowledge from outside and the informal channels are often used, this only denotes a less structured approach to the management of knowledge and less reliance on internal knowledge development than more advanced economies counterparts. Knowledge assimilation is carried out similarly to other contexts, whereas the reduced emphasis on transformation and the emphasis on innovation is a common characteristic of latecomer firms (see Petti et al. 2019a). Knowledge is internally diffused, 
verified and analyzed, as well as tested by employee's teams in the so-called 'testing environments', used to develop a standard solution for customers, usually by adapting the existing technologies for the development of new prototypes, mainly for small and medium enterprises' customers.

Therefore, in terms of innovation practices, regardless of the age and stage of development, enterprises surveyed rely on existing technologies to build offerings and products adapted to the needs of the local market. More often, changes brought do not even entail the product but the other components of the business model, reconfiguring them in such a way that the business model and/or its offering is new to the firm's market (and this often includes imported business models from abroad). This is referred to in the literature as 'secondary business model innovation' (Wu et al. 2010). Even when changes interest the product, these changes are usually not radical. In fact, all the firms surveyed use and combine existing technologies to generate a solution to an existing or new demand in the home market. This is consistent with the 'secondary innovation' (Wu et al. 2009) practices of Chinese latecomer firms detected in previous studies or at a similar stage or condition of development (see Petti and Zhang 2014). Whether new or established, latecomers' companies' innovation starts from the market and then gets to search and apply existing technology to create a solution, which is constantly and regularly updated to cater to a new demand. These companies usually do not develop any significant product innovation and are rather focused on quickly seizing new opportunities to serve their customers better; more keen on market opportunities than technological ones (see Petti et al. 2019b in this regard).

The success seems, therefore, to come more from services offered and business model, as well as peculiar local conditions, rather than from the technology and innovativeness of the products or their single components, as depicted in Table 4 above. The business model innovation of the firms surveyed was aimed mainly to capture value from innovation inside the company. This kind of innovation, to be successful, entails not only developing an appropriate business model but also sustaining that model in an environment that can be resistant to change. The business model practices of these firms reduced the risk by learning through targeted experiments with customers and partners before engaging fully with the market. The firms surveyed developed their business model understanding the way the parts of the model work together to create advantages, the customer set, the basis of competition and the channel, along with the differentiation that will attract customers (B2B-SME) and perhaps allow flexibility in pricing. Competitive advantage was built on a strategic asset-a unique product, differential power in the channel, a speed to market advantage. A disciplined approach to business model innovation created the quickest path to market for tech-based start-ups and firms; in addition, it increased the chances of success and sustainability in the local market. EMLCFs and start-ups continually react to large and small changes by a reposition to avoid emerging risks and seize opportunities. The most obvious changes are in the way that businesses sell to their customers, the way customers buy and the partners. In the above cases, all start-ups revised their key partners and customer relationships from the inception; this is because the market witnessed the entry of competitors and weakening relationships with existing customers. These enterprises are predisposed to changes as they continuously revisited their business model and searched for new opportunities.

In terms of performance in the market, two out of the three firms surveyed perceived their performance to rank ahead in terms of market share, operational effectiveness and market and financial performance. This testifies the viability of these practices in the specific context.

\subsection{Discussion}

Technological start-ups and firms can have a significant impact on society in terms of growth (Audretsch and Fritsch 2003; Wong et al. 2005) by "introducing innovations, creating change, creating competition and enhancing rivalry". The major findings of this 
study deal mainly with the first kind of impact, although the context traced gives a feeling about the dynamism of the overall competitive environment created by the technology startups' surge. In more detail, the case studies reveal three major findings. First, consistently with the latecomers' literature, of the firms surveyed, all follow an incremental, marketdriven, secondary innovation model, mainly based on soft business model and services innovations, with limited product and technology adaptations to peculiar local market needs. The focus on business model innovation is consistent with the catch-up stages, although, as compared with Chinese and earlier predecessors, the focus on the soft, rather than on the product and technology side is more marked. Second, the combination of the inherent market dynamism characterizing emerging environments and the institutional dynamism characterizing transitioning environments, such as Vietnam, create peculiar local conditions that latecomer firms need to face. In this specific study, these relate to the balance and effects of state support and market-based mechanisms. Related to this second aspect, there is the third, the interactions between institutional and organizational factors and the trade-offs that need to be tackled (at the macro-level) or dealt with (at the firm level), which in the specific case relate to long against short term decisions and their effects.

In the following, these findings are discussed in detail.

The cases performed in Vietnamese firms highlight, regardless of the age and stage of development, these firms rely on existing technologies to build offerings and product adaptations to the needs of the local market. By offerings, we mean that there may not even be changes in the product but just in the other components of the business model. This is business model innovation, defined as a reconfiguration of activities in the existing business model of a firm that is new to the product/service market in which the firm competes, a product/service offering that was not previously available to local customers. Since the reconfiguration of activities may require significant adaptations to local customer preferences and market infrastructures (in Vietnam, the Grab app is a case in point in these regards), the innovation practices of the specific cases analyzed fall in such definition consistently with the illustration of Wu et al. 2010). By product adaptations, we mean that although the products are changed, those changes are not radical. As a matter of fact, some of the firms surveyed use and combine existing technologies to generate a solution to an existing or new demand in the home market. Whether new or established, these companies' innovations start from the market and then get to search and apply existing technologies to create a solution, which is constantly and regularly updated to cater to new demand. A company surveyed reported to have modified its product 27 times, with only $30 \%$ of the features reported to be kept after each modification round.

Relating to the source of this knowledge, all the founders have international studies and experience. They usually refer to international markets for their business model and product configuration templates. Consistently with the above and latecomer firms in other contexts (such as China), the companies surveyed did not develop any significant innovation and are rather focused on quickly seizing new opportunities to serve their customers better, keener on market opportunities than technology ones, as observed in the works of Liu (2008) and Maksimov et al. (2014). Further, because of the age (younger on average), they are more focused on chasing high-potential gains. Even the latecomer firms that bring about some innovations, are not radical, but rather new-to-the-market ones, with the company more focused on services and systems' innovations. This is also quite clear in other emerging markets, where the success comes more from services offered and the business model (consistently with Wu et al. 2010), as well as peculiar local conditions (consistently with Liu 2008), rather than from the technology and innovativeness of the products or their single components. Take, for instance, WeChat in China or the drive to artificial intelligence applications in the country. This latter rests on a huge availability of usable data. The same points have also emerged for the most advanced case; the established technology firm analyzed in Vietnam.

To sum up, in these firms, what counts is developing new, comprehensive solutions rather than new technologies. This inevitably leads to a high rate of business model change, 
mainly in the partners, resources and customer relationships components, as well as in their cost structure. Often these changes entail the entire business model. The transition from Tencent QQ to WeChat is a relevant example of such a kind of architectural business model innovation.

The management of knowledge in emerging markets' latecomer firms appears, therefore, focused on upstream knowledge acquisition and assimilation processes, mainly from abroad. Knowledge creation is rather limited to the adaptation of knowledge gained from abroad to local conditions and needs in order to be swiftly exploited to cater to market demand with localized versions of products, more often developed more through services and (secondary) business model innovations rather than product ones. This, especially at earlier stages of catching up and of the companies' life, makes innovation management and strategies rather incremental and market-driven (as well as institutionally driven). Therefore, consistently with other studies and the literature (Guan et al. 2006; Chen and Yuan 2007; Li and Kozhikode 2008; Liu 2008; Wu et al. 2009, 2010; Chen et al. 2011; Maksimov et al. 2014, Petti et al. 2019a, 2019b), the latecomer firms analyzed emerged as relying on what is being called a market-oriented innovation or secondary/business model innovation. Whatever called, is a kind of innovation focused on the improvement and adaptation of existing business models, products or technologies (in this order), to suit the specific needs or characteristics of the local market, by either lowering costs (but not quality) or by customizing product features, all with steady responsiveness to the market.

By looking with perspective, the cases analyzed in Vietnam are not so different from cases analyzed in China ten years earlier. In addition, by comparing latecomer firms in the two countries, it can be clearly seen that different stages of catch-up lead to different innovation practices in nature and degree. Where in Vietnam we witnessed more business model soft-innovations, in China, there is now more product and technology adaptation and improvement in comparable latecomer companies, whereas innovation of an advanced degree in certain sectors is already a reality.

These are naturally effective strategies in emerging settings where markets are inherently dynamic. However, while considering this, a researcher needs to see that emerging market dynamism is not only a characteristic of the industrial environment (see Li et al. 2014) but also of institutional ones, especially in previously socialist and mixed economies, which are characterized by institutional transitions, such as Vietnam now and China before. In these regards, the study also leads to the practical need for emerging markets' latecomer firms to prepare for the strengthening of institutions in transitional environments instead of sheltering, or worse, riding their imperfections. It may pay in the short term, but not in the long one. These latter considerations are deemed particularly relevant as they entail all other emerging economies, and even those developed economies, as far as the reach of strong government role and involvement, imperfect market institutions and corporate political actions. However, in this regard, the situation of Vietnam is particularly interesting. In fact, in another comparative study, the better knowledge acquisition performance through exports of Chinese firms against all their Asian counterparts may well be attributed to the support they can enjoy from the mixed model, industrial policies and the powerful state-owned export intermediaries (Di Cintio 2020) contrasts with their Vietnamese counterparts. For the latter, the marginalization and dependence within global value chains and the underdevelopment of transformative capacity are, in fact, attributed, if not blamed, to the excessive reliance of the country on free-market mechanisms.

The latter highlight the effect of the overall institutional setting in which emerging market firms operate and is another factor policy-makers have to consider. Our findings are consistent with institutional theory in revealing as differences in institutional settings generate different firms' innovation responses. In turn, this determines the stakes of their short and long terms catch-up success. Therefore, policy-makers should evaluate beforehand and in an intertemporal and comprehensive perspective not only their policies development but also the overall context in which they are deployed. This means to try to anticipate the possible distortive or compensative effects it may play on a firm's innovation, 
and therefore, on the policy objectives envisaged (comprehensive micro-macro perspective), also as a result of firm's practices, responses and interactions in the long run (intertemporal perspective).

Therefore, with particular reference to upgrading policies, our study shows catch-up cannot be taken for granted, and not all policy recipes are good for all countries, could stand the test of time or even their own diffusion and success. For instance, taking a developmental stance from the Vietnamese government, with preferential policies and indiscriminate support to latecomer firms with public funding, may just promote the same kind of adverse selection generated by pro-start-up policies lamented by Shane (2009). These policies proved not to work beyond the short-term, although unleashing composition effects, which consequently have been worsening in excess capacity and competition, as happened, for instance, in the World photovoltaic industry as a consequence of the Chinese post-financial-crises stimulus package (see Andreozzi 2012). In addition, with a raging trade war waged against China on its industrial policies, allegations of 'predatory' and 'mercantilist practices' and without the dimensions of China, could such hypothetical turn-around in Vietnamese policies be effective?

The reply would probably be in trying to target innovation and entrepreneurship policies by investing in the enhancement of firms' competitiveness and by raising the awareness and the need of a due intention and attention to the capacity to learn and absorb, as well as the payoffs of doing so. This means work on helping companies with the means to fight in the market context rather than fighting in their place. If there is something the government has to do, it is to work on the enabling and facilitating conditions that can make an environment conducive to attract back and especially retain talents at home. This is one of the differences emerging while comparing Vietnam to China 10-years-after. The staggering impression is that, where in 2010 Chinas entrepreneurs and talents abroad were flocking back and domestic educated/based entrepreneurs and talents were already contending markets and positions to returnees, in Vietnam, there are still a lot of young people who want to go undertake their career abroad. Due to pollution, food and health insecurity and others, such as the backdrops of state's weight in certain areas.

The latter considerations about policy implications led the attention to the interaction between institutional and organizational factors in latecomer firm's innovation catch-up. In this regard, our study demonstrated that not all interactions among these factors are positive. Trade-offs are at play; for instance, a trade-off between the long-term benefits of markets opening against short-term difficulties faced by local companies. Nonetheless, the major effects are produced when such interactions are positive, as in the cases when institutions support and are supported by the development of organizational capabilities, strategies and changes. Notwithstanding, in the meantime, many more other enterprises' innovation efforts are geared more towards the acquisition and limited adaptations of existing technologies to produce cheaper, simpler, good-enough and customized products rather than on the development of radically new ones. This is because, in emerging market settings, the government support tends to concentrate on few champions or big-state firms, leaving the mass of companies struggling with a lack of adequate investments, support and more bureaucracy. Most of these firms suffer from the distortion of not only an excessive or unbalanced role of the state but also of the not fully-fledged market mechanisms and the recourse to informal institutions that weakens the overall innovation environment and firm's technological and innovation learning.

In these conditions, understanding and responding rapidly, accurately and in a timely fashion to market needs is still more important than technology development. Moreover, tailoring the original business model from advanced economies to local customer preferences and the market infrastructure is the way to do it, at least in the first versions of a product, as we have seen not only in Vietnam but also in many Chinese SMEs.

At the very least, the ability to rapidly develop an appropriate product and put it on as many shelves as possible, and the ability to quickly design and manufacture upgraded versions of the product before imitators catch up, are paramount, probably more than 
seeking legal protection of intellectual property. Imitation is a key example of how the EMLCFs practices are not just a matter of market imperfections of the evolution of the institutional environment. Weak protection of intellectual property rights is just one of the reasons for diffused imitation and, apparently, not the main one. The other reasons lie in a number of other aspects that make the emerging markets very different from the one in which US and EU technology enterprises work. Among these vast markets, their hyper-competitiveness, differential treatment, income disparity, the availability of foreign technologies and export-based or mixed models do not leave much room for a real innovation-driven economy to flourish, although the successes and performance of some big firms have occurred.

\section{Conclusions}

In this paper, we tried to shed light on the dynamics of technological catch-up through entrepreneurship in emerging markets' latecomer firms through the analysis of how innovative entrepreneurship works in three Vietnamese technology exemplar firms at different stages of their lifecycle. These firms' performance testifies the viability of technological catch-up patterns followed in the specific Vietnamese context, characterized by business model and secondary innovations that rest upon solutions' rather than technologies' innovation, which push competition with incumbents on factors these companies can compete (see Wu et al. 2010). In fact, the overall understanding from the cases investigated was that their business models are composite, modular and adaptive. The technologies adapted were typically known and not new to the industry. Where found, product innovations were mainly based on modification adaptations of existing products and technologies to develop new (to the firm) products for a different context following a predominantly market-oriented innovation strategy. As the cases used confirm, but in a new and institutionally peculiar context, the latecomer firms can catch up to the findings in the literature. In this regard, similar implications about the temporary nature of this advantage and the need to push on internal development in order to not remain lagging and marginalized (see Petti et al. 2019a, 2019b) also applies, especially in Vietnam. The comparisons with the Chinese case highlight the market mechanism at work and the softer, non-appropriable nature of the business model innovation advantage exposes latecomer firms to earlier and stronger (international) competition than their Chinese counterparts. The comparisons with this latter also highlight the phased nature of catch-up patterns; that is, different stages of catch-up lead to different innovation practices in nature and degree.

Nonetheless, although exemplar, the limited number of cases on which these theoretical implications are based, warns about the preliminary nature of the insights gained. As a matter of fact, the limited time and resources available for data collection, undertaken in the context of an internship, part of which, given the newness of the context, was dedicated to studying and understanding, limited the possibility to collect more cases, ideally in different parts of Vietnam. Therefore, the generalizability of the findings needs further cases to be undertaken within the same three stages of development and in different parts of Vietnam, especially in the South, and then in other neighboring countries.

Interesting signals for further research are the supposedly adverse impacts of market mechanisms and the possibility to undertake fully-fledged industrial policies in comparison with the Chinese cases and, with particular reference to transition economies, the impacts of the relationships between the inherent market and institutional dynamism on firms' technological catch-up. We believe both directions will contribute to the advancement of the renewed debate between the developmental state against the market-based development in technological catch-up.

Author Contributions: Conceptualization, C.P.; methodology, C.P. and T.N.P.; validation, C.P. and T.N.P.; formal analysis, M.P.T., T.T.H. and V.V.P.; investigation, M.P.T., T.T.H. and V.V.P.; resources, C.P. and M.N.D.T.; data curation, M.P.T., T.T.H. and V.V.P.; writing—original draft preparation, V.V.P.; writing—review and editing, C.P. and T.N.P.; visualization, M.N.D.T.; supervision, C.P., M.N.D.T.; 
project administration, C.P., M.N.D.T.; funding acquisition. All authors have read and agreed to the published version of the manuscript

Funding: This research has received funding from the European Union's Horizon 2020 research and innovation programme under the Marie Sklodowska-Curie grant agreement No 734447.

Institutional Review Board Statement: Not applicable.

Informed Consent Statement: Informed consent was obtained from all subjects involved in the study.

Data Availability Statement: Not applicable.

Conflicts of Interest: The authors declare no conflict of interest.

\section{Appendix A. Case Study Interview Guide Excerpt (Questions)}

1. What are your Company key products

2. Pick one of them, can you tell us the story on how did you develop it from the inception to the market?

- What was the spark that made you developed these products?

- What knowledge and technology was necessary to develop this product?

- What knowledge did you have already and what knowledge were you in need?

- In this last regard:

How did you identified the knowledge you were in need?

What where the main sources/channels from which did you get that knowledge

- customers and/or your customers' clients;

- suppliers, competitors, consultants, other businesses, private R\&D labs;

- universities \& research institutes, government research institutes, other government bodies or agencies;

- professional conferences, meetings, trade associations, technical/trade press, computer databases, fairs, exhibitions;

- other

How did you acquired this knowledge?

How did you ensured the diffusion/communication of this knowledge internally? For instance cross-departmental meetings, personnel mobility, IT systems, knows-who ...

How did you processed this knowledge?

And how did you incorporate in your production processes and new product?

3. Did you developed any patent (if so which kind) from this knowledge? Why did you engaged in that patent development?

4. In general:

- do the search for relevant information concerning your business is everyday business within the company?

- in your company is there a quick and effective information flow so that your able to promptly recognize shifts in your market, rapidly understand new opportunities to serve your customers and correctly analyse and interpret changing market demands?

- $\quad$ are your employees able/trained to transform external and internal information and knowledge into new knowledge and use it in their practical work?

- were you able to work more effectively as a consequence of this new knowledge (i.e., improve processes, develop new products quicker, improve time to market)?

- how would you rate your company on these in comparison with your competitors? Lagging, Parity or Ahead? 
5. Talking about your business model, what is your business model/like?

- Did you changed it since you started? How many times roughly?

- Did you changed your business model or launched new ones recently?

If yes, how may changes and/or how many new business models? And in which components (Key partners, Key activities, Key resources, Value propostion/offeringCustomer segments, Channels, Customer relationships, Cost structure, Revenue structure)

6. In general, talking about your innovation in your company:

- how many new products you developed over the last 3 years?

- what is the value of new product sales on total sales revenue in $\%$ ?

- what is the average time-to-market for developing new products? (months)

- How many of these new products have been introduced to the market?

- How would you rate your customers' satisfaction on these products?

- Are your innovation investments mainly focused on extending existing product lines or creating new ones?

- Your new products are mainly: modifications of existing products, 1st time for your company, 1st time in your market or new to the World?

7. How would you rate your overall market and financial performance as compared to yours main three competitors? In terms of market share, revenues, profits and cost effectiveness? Lagging, Parity or Ahead?

8. Enterprise data:

- Company's age

- Ownership (state-owned, private-owned, other)

- Market share/position into the principal market

- Overall revenues (in USD millions or VNDs units)

- Number of employees

- Export ratio in \%

- Industry

9. Interviewee data:

- Tenure within the company (Years)

- Education (Kind and Level), in Vietnam or Abroad? (Where)

- Experience with the industry (Years) in Viet or Abroad? (Where)

10. Company innovation strategy:

- Market-oriented, Technology-oriented or led by cost advantage

\section{References}

Abramovitz, Moses. 1986. Catching Up, Forging Ahead, and Falling Behind. The Journal of Economic History 46: 385-406. [CrossRef] Acs, Zoltan J., and Laszlo Szerb. 2007. Entrepreneurship. Economic Growth and Public Policy. Small Business Economics 28: 109-22. [CrossRef]

Acs, Zoltan J., David B. Audretsch, and Erik E. Lehmann. 2009. The Knowledge Spillover Theory of Entrepreneurship. Small Business Economics 32: 15-30. [CrossRef]

Acs, Zoltan, Thomas Åstebro, David Audretsch, and David T. Robinson. 2016. Public Policy to Promote Entrepreneurship: A Call to Arms. Small Business Economics 47: 1-17. [CrossRef]

Amsden, Alice H. 1989. Asia's Next Giant: South Korea and Late Industrialization. New York: Oxford University Press.

Andreozzi, Marco. 2012. Solar photovoltaic industry development from the early 1990s to world leadership. In Technological Entrepreneurship in China. How Does It Work? Edited by Claudio Petti. Cheltenham and Northampton: Edward Elgar.

Audretsch, David, and Michael Fritsch. 2003. Linking entrepreneurship to growth: The case of West Germany. Industry and Innovation 10: 65-73. [CrossRef]

Baumol, William J. 1990. Entrepreneurship_Productive, Unproductive, and Destructive. Journal of Political Economy 98: 893-921. [CrossRef] 
Block, Joern H., Christian O. Fisch, and Mirjam Van Praag. 2017. The Schumpeterian entrepreneur: A review of the empirical evidence on the antecedents, behaviour and consequences of innovative entrepreneurship. Industry and Innovation 24: 61-95. [CrossRef]

Chen, Yanying, and Yijun Yuan. 2007. The innovation strategy of firms: Empirical evidence from the Chinese high-tech industry. Journal of Technology Management in China 2: 145-53. [CrossRef]

Chen, Jiang, Yidi Guo, Shuo Huang, and Hengyuan Zhu. 2011. The determinants of the choice of innovation source for Chinese firms. International Journal of Technology Management 53: 44-68. [CrossRef]

Cumming, Douglas J., and Eileen Fischer. 2012. Publicly Funded Business Advisory Services and Entrepreneurial Outcomes. Research Policy 41: 467-81. [CrossRef]

Di Cintio, Marco. 2020. Knowledge and Export Modes: Which Export Strategy Boosts Firms Knowledge Acquisition? The Review of Economic Analysis 12: 461-83.

Di Tommaso, Marco Rodolfo, and Antonio Angelino. 2019. Vietnamese industrial development: Following Washington on the road to Beijing. International Journal of Emerging Markets 16: 241-63. [CrossRef]

Dutz, Mark A., Janusz A. Ordover, and Robert D. Willig. 2000. Entrepreneurship, access policy and economic development: Lessons from industrial organization. European Economic Review 44: 739-47. [CrossRef]

Eisenhardt, Kathleen M. 1989. Building Theories from Case Study Research. Academy of Management Review 14: 532-45. [CrossRef]

Fairlie, Robert W., Kanika Kapur, and Susan Gates. 2011. Is Employer-based Health Insurance a Barrier to Entrepreneurship? Journal of Health Economics 30: 146-62. [CrossRef] [PubMed]

Fairlie, Robert W., Kanika Kapur, and Susan Gates. 2016. Job-lock: Evidence from a Regression Discontinuity Design. Industrial Relations 55: 92-121. [CrossRef]

Fritsch, Michael, and Pamela Mueller. 2007. The Persistence of Regional New Business Formation Activity over Time-Assessing the Potential of Policy Promotion Programs. Journal of Evolutionary Economics 17: 299-315. [CrossRef]

Gershenkron, Alexander. 1962. Economic Backwardness in Historical Perspective. Cambridge: Harvard University Press.

Guan, Jian Cheng, Chiu Kam Mok, Richard C. M. Yam, Kwai-Sang Chin, Kwai-Sang Chin, and Pun Kit Fai. 2006. Technology transfer and innovation performance: Evidence from Chinese firms. Technological Forecasting and Social Change 73: 666-78. [CrossRef]

Hobday, Mike. 1995. East Asian latecomer firms: Learning the technology of electronics. World Development 23: 1171-93. [CrossRef]

Li, Jiatao, and Rajiv Krishnan Kozhikode. 2008. Knowledge management and innovation strategy: The challenge for latecomers in emerging economies. Asia Pacific Journal of Management 25: 429-50. [CrossRef]

Li, Yuan, Haowen Chen, Yi Liu, and Mike W. Peng. 2014. Managerial ties, organizational learning, and opportunity capture: A social capital perspective. Asia Pacific Journal of Management 31: 271-91. [CrossRef]

Liu, Xielin. 2008. China's Development Model: An Alternative Strategy for Technological Catch-Up. SLPTMD Working Paper Series; No. 020. Oxford: University of Oxford.

Maksimov, Vladislav, Jinyun Sun, Yadong Luo, and Stephanie Lu Wang. 2014. From imitation to imutation: Conditions and consequences. Academy of Management Annual Meeting 2014: 12983. [CrossRef]

Malerba, Franco. 2002. Sectoral systems of innovation and production. Research Policy 31: 247-64. [CrossRef]

Mathews, John A. 2002. Competitive advantages of the latecomer firm: A resource-based account of industrial catch-up strategies. Asia Pacific Journal of Management 19: 467-88. [CrossRef]

Minniti, Maria. 2008. The Role of Government Policy on Entrepreneurial Activity: Productive, Unproductive or Descructive? Entrepreneurship Theory and Practice 32: 779-90. [CrossRef]

North, Douglass C. 1990. Institutions, Institutional Change, and Economic Performance. Cambridge: Cambridge University Press.

Petti, Claudio, and Shujun Zhang. 2014. Factors Influencing Technological Entrepreneurship in Chinese Technology Firms. Evidence from Guangdong. International Journal of Technology Management 65: 70-95. [CrossRef]

Petti, Claudio, Yongli Tang, and Alessandro Margherita. 2019a. Technological innovation vs. technological backwardness in latecomer firms: An absorptive capacity perspective. Journal of Engineering and Technology Management 51: 10-20. [CrossRef]

Petti, Claudio, Yongli Tang, Elisa Barbieri, and Lauretta Rubini. 2019b. The role of absorptive capacity and opportunity capture in latecomer firms' innovation catch-up. Knowledge Management Research E Practice 18: 297-309.

Shane, Scott. 2009. Why encouraging more people to become entrepreneurs is bad public policy. Small Business Economics 33: 141-49. [CrossRef]

Tech Sauce. 2021. Available online: https://techsauce.co/tech-and-biz/vietnam (accessed on 26 August 2021).

Westphal, Larry E. 2002. Technology Strategies for Economic Development in a Fast Changing Global Economy. Economics of Innovation and New Technology 11: 275-320. [CrossRef]

Wong, Poh Kam, Yuen Ping Ho, and Erkko Autio. 2005. Entrepreneurship, innovation and economic growth: Evidence from GEM data. Small Business Economics 24: 335-50. [CrossRef]

$\mathrm{Wu}$, Xiaobo, Rufei Ma, and Guannan Xu. 2009. Accelerating Secondary Innovation through Organizational Learning: A Case Study and Theoretical Analysis. Industry and Innovation 16: 389-409. [CrossRef]

Wu, Xiaobo, Rufei Ma, and Yongiiang Shi. 2010. How do Latecomer Firms Capture Value from Disruptive Technologies. A Secondary Business-Model Innovation Perspective. IEEE Transactions on Engineering Management 57: 51-62. [CrossRef]

Yin, Robert K. 1994. Case Study Research Design and Methods: Applied Social Research and Methods Series, 2nd ed. Thousand Oaks: Sage. 